\title{
Oxygenated Hemoglobin
}

National Cancer Institute

\section{Source}

National Cancer Institute. Oxygenated Hemoglobin. NCI Thesaurus. Code C126120.

Hemog lobin where the heme group has formed a reversible complex with oxygen (O2) in the lungs. This molecule is found in the systemic arteries and transports $\mathrm{O} 2$ from the lungs to the tissues where it is readily released. 